Pesq. Vet. Bras. 36(5):423-430, maio 2016 DOI: $10.1590 / \mathrm{S} 0100-736 \mathrm{X} 2016000500012$

\title{
Isolation, expansion and differentiation of mesenchymal stromal cells from rabbits' bone marrow ${ }^{1}$
}

\author{
Renato B. Eleotérioº ${ }^{2}$ Rodrigo V. Sepúlveda², Emily C.C. Reis², Fabrício L. Valente ${ }^{2}$ \\ and Andréa P.B. Borges ${ }^{2 *}$
}

\begin{abstract}
Eleotério R.B., Sepúlveda R.V., Reis E.C.C., Valente F.L. \& Borges A.P.B. 2016. Isolation, expansion and differentiation of mesenchymal stromal cells from rabbits' bone marrow. Pesquisa Veterinária Brasileira 36(5):423-430. Departamento de Veterinária, Universidade Federal de Viçosa, Rua Peter Henry Rolphs s/n, Campus Universitário, Viçosa, MG 36570-000, Brazil. E-mail: andrea@ufv.br

Tissue engineering has been a fundamental technique in the regenerative medicine field, once it permits to build tri-dimensional tissue constructs associating undifferentiated mesenchymal cells (or mesenchymal stromal cells - MSCs) and scaffolds in vitro. Therefore, many studies have been carried out using these cells from different animal species, and rabbits are often used as animal model for in vivo tissue repair studies. However, most of the information available about MSCs harvesting and characterization is about human and murine cells, which brings some doubts to researchers who desire to work with a rabbit model in tissue repair studies based on MSCs. In this context, this study aimed to add and improve the information available in the scientific literature providing a complete technique for isolation, expansion and differentiation of MSCs from rabbits. Bone marrow mononuclear cells (BMMCs) from humerus and femur of rabbits were obtained and to evaluate their proliferation rate, three different culture media were tested, here referred as DMEM-P, DMEM'S and $\alpha$-MEM. The BMMCs were also cultured in osteogenic, chondrogenic and adipogenic induction media to prove their multipotentiality. It was concluded that the techniques suggested in this study can provide a guideline to harvest and isolate MSCs from bone marrow of rabbits in enough amount to allow their expansion and, based on the laboratory experience where the study was developed, it is also suggested a culture media formulation to provide a better cell proliferation rate with multipotentiality preservation.
\end{abstract}

INDEX TERMS: Mesenchymal stromal cells, rabbit, bone marrow stem cells, cell therapy, tissue engineering, regenerative medicine.

RESUMO.- [Isolamento, expansão e diferenciação de celulas tronco mesenquimais oriundas da medula óssea de coelhos.] A engenharia de tecidos tem sido uma técnica fundamental no campo da medicina regenerativa, uma vez que permite a criação de peças teciduais tri-dimensionais por meio da associação de células mesenquimais indiferenciadas (ou células estromais mesenquimais - CEMs) e moldes de biomateriais in vitro. Assim, muitos estudos têm sido realizados utilizando estas células oriundas de diferentes espécies animais, e os coelhos são frequentemente

\footnotetext{
${ }^{1}$ Received on December 11, 2015.

Accepted for publication on February 10, 2016

${ }^{2}$ Departamento de Veterinária, Universidade Federal de Viçosa (UFV), Rua Peter Henry Rolphs, s/nº, Campus Universitário, Viçosa, MG 36570000, Brazil. Pesquisa de doutorado com apoio CAPES e CNPq. *Corresponding author: andrea@ufv.br
}

utilizados como um modelo animal para estudos in vivo de reparação tecidual. No entanto, a maioria das informações disponíveis sobre a coleta e caracterização de CEMs referem-se às células humanas e murinas, o que traz algumas dúvidas para pesquisadores que desejam trabalhar com coelhos em estudos de reparação de tecidos baseados em CEMs. Neste contexto, o presente estudo objetivou contribuir e aprimorar as informações disponíveis na literatura científica fornecendo uma técnica completa para o isolamento, expansão e diferenciação das MSCs de coelhos. Células mononucleares da medula óssea (CMMOs) do úmero e fêmur de coelhos foram obtidas e, para avaliar sua taxa de proliferação, três meios de cultura diferentes foram testadas, aqui referidos como DMEM-P, DMEM'S e $\alpha$-MEM. As CMMOs também foram cultivadas em meios de indução osteogênico, condrogênico, e linhagens adipogênico para 
provar a sua multipotencialidade. Concluiu-se que as técnicas sugeridas neste estudo podem fornecer um guia para a coleta e isolamento de CEMs da medula óssea de coelhos em quantidade suficiente para permitir a sua expansão e, com base na experiência de laboratório onde o estudo foi desenvolvido, é também sugerida uma formulação de meio de cultivo para proporcionar uma melhor taxa de proliferação celular com preservação da multipotencialidade.

TERMOS DE INDEXAÇÃO: Células tronco mesenquimais, medula óssea, coelhos, terapia celular, engenharia de tecidos, medicina regenerativa.

\section{INTRODUCTION}

Tissue engineering has emerged as a promising alternative therapy for clinical use, once it can provide a controllable system for cell function, biological development and pathogenesis studies (Griffith \& Naughton, 2002). Because of their ability in differentiating into a variety of cell types and relative ease of harvesting, isolating and expansion, undifferentiated stromal cells (or mesenchymal stromal cells MSCs) have become an attractive cell population to use in tissue engineering (Dawson et al. 2008). Thus, these cells are often associated to different biomaterials in several studies, providing tissue engineering techniques to improve the tissue regeneration process (Kotobuki et al. 2005).

At the same time, the regenerative medicine community recognizes the need to create a database of techniques that apply undifferentiated stromal cells for clinical purpose. As rabbits has a faster skeletal change and bone turnover when compared to other species (Castañeda et al. 2006), they are usually the first choice of researchers as animal model to assess the in vivo bone repair (Li et al. 2015). Although there are some studies available in the scientific scope about rabbits' MSCs utilization to repair different tissues (Im et al. 2001, Ma et al. 2015, Mehrabani et al. 2015, Pelizzo et al. 2015, Semyari et al. 2015) these studies usually fail at some point for not mentioning the whole method used to harvest and/or to prove that these cells are really undifferentiated stromal cells.

For multipotent mesenchymal stromal cells characterization, the International Society for Cellular Therapy (ISCT) establishes that they must have a fibroblastoid morphology, must be adherent to plastic, and their multipotentiality needs to be proved by inducing osteogenic, chondrogenic and adipogenic differentiation; besides, presence of some cell surface markers and absence of others must be proved (Dominici et al. 2006). However, a study published by Lee et al. (2014) showed that there is not a stablished consensus about specific surface markers present on rabbits' undifferentiated stromal cells as it is already consolidated for human and murine cells; in addition, these same authors suggested that surface markers vary between species; for example, surface markers CD73, CD90 and CD105 are often used to identify human undifferentiated mesenchymal stem cells that are not expressed on similar cells from rabbits. Thus, this study proved that it is not accurate to use surface markers of human undifferentiated stromal cells as reference to characterize those cells isolated from other species.
Therefore, the lack of information about rabbits' MSCs harvesting and characterization can make difficult to reproduce some studies and, in some cases, this issue also brings doubts about whether these studies are really using undifferentiated stromal cells.

In this context, a complete method was elaborated to isolate, characterize and to differentiate primary mononuclear cells (BMMCs) from rabbits' bone marrow. Adapting some methods already established by other researchers and using as criteria the presence of fibroblastoid plastic-adherent cells and their ability to differentiate into the three cell lineages established by ISCT, the aim of this study was to make available a guide of techniques for researches that usually work with MSCs from a rabbit model in their tissue engineering and regenerative medicine experiments. Thereby, it is believed that cell procedures discussed hereafter may be helpful for in vitro experiments of undifferentiated cells and biomaterials interactions and also for in vivo studies of tissue reparation.

\section{MATERIALS AND METHODS}

\section{Ethics statement}

All following experiments were performed at the Federal University of Viçosa (UFV)/MG, Brazil and they were approved by the Ethics Committee on Animal Use of UFV (CEUA/UFV), as certified in Case 52/2013. Rules for use of animals in research were strictly followed.

\section{Isolation and culture of bone marrow mononuclear cells (BMMCs)}

After premedication with tramadol hydrochloride ${ }^{3}(6 \mathrm{mg} / \mathrm{kg} /$ IM), general anesthesia was induced with Tiletamine/zolazepam ${ }^{4}$ $(30 \mathrm{mg} / \mathrm{kg} / \mathrm{IM})$ and maintained with isoflurane ${ }^{5}$ diluted in $100 \%$ oxygen by anesthesia mask. Then, surgical field was properly prepared and the marrow was harvested from femoral and humerus of five New Zealand rabbits, with six months old.

Using protocols of Tognoli et al. (2009) and Eurides et al. (2010) as reference, bone marrow was obtained in aseptic conditions by percutaneous puncture with a hypodermic needle 18 $\mathrm{G}$ in rotational movements, followed by aspiration using a $10 \mathrm{ml}$ syringe containing heparin diluted in $2 \mathrm{ml}$ of sterile phosphate buffered saline solution (PBS) at a concentration of $5000 \mathrm{U} / \mathrm{ml}$. In femur, punctures were done in the region of trochanteric fossa, whilst in forelimb the needle was inserted into humerus tuberosity; in both cases, the limb was pulled caudally.

Bone marrow of all limbs were extracted in the maximum amount possible. During aspiration, the syringe was carefully moved to promote homogenization between heparin and aspirated. When the aspirated marrow volume exceeded $2 \mathrm{ml}$ in each member, more heparin was added in an amount required to maintain the rate of $0.1 \mathrm{ml}$ heparin for each $2 \mathrm{ml}$ of bone marrow. After aspiration, samples were transported immediately to the cell culture laboratory in an insulated box containing ice.

Meloxicam ${ }^{6}$ were administered at a dosage of $0.2 \mathrm{mg} / \mathrm{kg}$ subcutaneously immediately after the puncture, and then one more dosage was performed daily for 3 days.

Under class II laminar flow cabinet, the total marrow aspirated of each member was filtered separately, to avoid contamination between samples, by $100 \mu \mathrm{M}$ cells-strainers coupled to a

\footnotetext{
${ }^{3}$ Tramadon $^{\circledR}$, Cristália, Brazil; ${ }^{4}$ Zoletil $^{\circledR}$, Virbac, Brazil; ${ }^{5}$ Isoflurane ${ }^{\circledR}$, Cristália, Brazil; ${ }^{6}$ Maxicam ${ }^{\circledR}$, Ouro Fino, Brazil.
} 


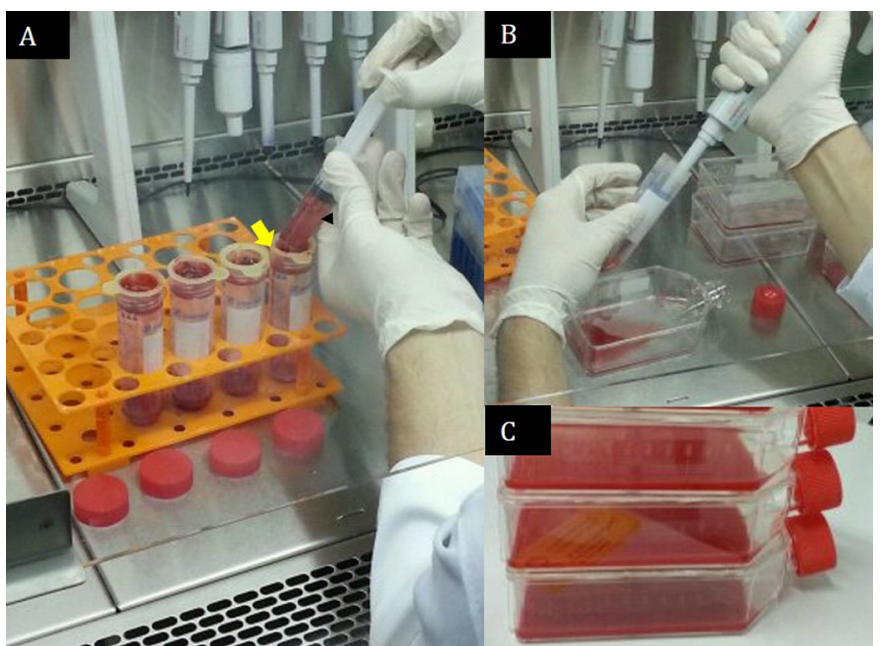

Fig.1. Rabbits' bone marrow aspirate being processed under class II laminar flow cabinet. (A) Marrow aspirate filtering through $100 \mu \mathrm{m}$ cell strainer (yellow arrow) coupled to a $50 \mathrm{ml}$ tapered bottom tube. (B) Transference of the resulting solution to T75 culture flasks after filtration. (C) T75 culture flasks containing the culture media and the bone marrow aspirate filtrated.

$50 \mathrm{ml}$ tapered bottom tube (Fig.1A), in order to remove bone fragments and fat content.

To perform the initial count of mononuclear cells, $0.5 \mathrm{ml}$ was taken from the filtrated and treated with $4.5 \mathrm{ml}$ of ammonium chloride $10 \%$ solution at $4^{\circ} \mathrm{C}$ for 10 minutes to cause lysis of red blood cells and thus allow the BMMCs identification. Next, the solution was centrifuged ${ }^{7}$ at $1500 \mathrm{rpm}$ for five minutes, supernatant was discarded and cell pellet was resuspended in $1 \mathrm{ml}$ of PBS. A $50 \mu \mathrm{l}$ aliquot of the resuspended was mixed with $50 \mu \mathrm{l}$ of $0.4 \%$ Trypan Blue ${ }^{8}$ for manual counting using a Neubauer chamber and inverted light microscopy. Remanent solution that received ammonium chloride was discarded and the filtrated remainder was transferred (Fig.1B) to T75 culture flasks containing culture media (Fig.1C).

To determine an optimum culture media which could provide better cell adaptation, BMMCs were isolated in three different media and then a cell proliferation assay was performed for each media, which is described in the next section. The amount of media added was determined subtracting the minimum volume indicated for T75 flask $(8 \mathrm{ml})$ by the volume obtained after filtration, and it was adopted no more than $4 \mathrm{ml}$ of filtrate per flask. To ensure mononuclear cells adhesion, culture flaks were incubated for three days $\left(37^{\circ} \mathrm{C}\right.$ and $\left.5 \% \mathrm{CO}_{2}\right)$ without media changing. After these first three days of incubation, culture media was replaced without prior washing with PBS. Further media changes were made every two or three days with carefully PBS washing prior to addition of fresh media. When small cell clusters were observed around the flask, a first trypsinization with $4 \mathrm{ml}$ of $0.1 \%$ trypsin-EDTA ${ }^{9}$ solution diluted in PBS was performed in order to promote a better cells distribution on the flask surface and thus improving the intercellular interactions.

Passages were done always when cell confluence of approximately $80-90 \%$ was reached and cells were replaced in T75 culture flasks respecting the density of 4.000 cells $/ \mathrm{cm}^{2}$.

\section{BMMCs' proliferation}

In order to determine an optimum culture media for BMMCs adaptation, a proliferation assay was carried out in triplicate for three different culture media. A media often referred in the scientific literature, here called pure DMEM (DMEM-P), which consisted of low glucose DMEM ${ }^{10}$ plus $5 \%$ common fetal bovine serum $^{11}$ (FBS) and 10\% antibiotic/antimycotic solution $(0.1$ $\mathrm{g}$ of penicillin $\mathrm{A}^{12}, 1 \mathrm{ml}$ of gentamicin ${ }^{13}$ at $50 \mu \mathrm{g} / \mathrm{ml}$ and $0.3 \mathrm{ml}$ of anfotericin $\mathrm{B}^{14}$ at $1 \mathrm{mg} / \mathrm{ml}$ for $100 \mathrm{ml}$ of PBS), and two other combinations of culture media were tested. The second media was called $\alpha$-MEM and consisted of $\alpha$-MEM media ${ }^{15}$ plus $10 \%$ solution antibiotics/antimycotics, 15\% Qualified Fetal Bovine Serum $^{\circledR 16}, 0.4 \%$ L-glutamine ${ }^{17}$, and $0.4 \%$ non-essential amino acids solution ${ }^{18}$. The last media tested was called DMEM'S and consisted of $37.1 \%$ DMEM Advanced ${ }^{\circledR}$ and 37.1\% DMEM without glucose $\mathrm{e}^{19}$, with supplementation identical to that specified for the second media.

For the BMMCs proliferation analysis, $4 \times 10^{4}$ cells at third passage were incubated in three wells of a 6 well plate. In total, 10 plates were used for each media tested. Plates were maintained in the incubator and had their media changed every two or three days. Every 24 hours, one plate of each media was trypsinized and then manual cell counting was performed. Data was submitted to normality statistical test and then analyzed by Tukey test post ANOVA $(\mathrm{p}<0.05)$.

\section{BMMCs' differentiation}

Primary mononuclear cells at third passage, cultured in DMEM'S media, were trypsinized and incubated in triplicate under osteogenic adipogenic and chondrogenic induction media, as established by Sarugaser et al. (2009). For each lineage, two different media were prepared, and, therefore, it was performed two differentiation tests in triplicate for each lineage. One induction media is reported below in the description of each differentiation protocol and it refers to addition of differentiation inductor factors proposed by Sarugaser et al. (2009) for each lineage. The second media refers to L-glutamine and non-essential amino acids addition to that media proposed by Sarugaser et al. (2009), adjusted in the same proportion as described for DMEM'S and $\alpha$-MEM proliferation assays.

For osteogenic culture, primary cells were plated with 2 $\mathrm{ml}$ of DMEM'S media per well. Once reached $60 \%$ of confluence, DMEM'S media was removed and osteogenic differentiation was induced adding $2 \mathrm{ml}$ of osteogenic media composed of 44\% DMEM Advanced ${ }^{\circledR}$, 44\% glucose-free DMEM, 5\% Qualified Fetal Bovine Serum ${ }^{\circledR}, 7 \%$ antibiotic/antimycotic solution and $1 \%$ dexamethasone $10 \mathrm{nM}^{20}$ diluted in ethanol. On the third culture day, $20 \mu \mathrm{L}(1 \%$ of the $2 \mathrm{ml}$ of induction media) of $500 \mathrm{mM}$ $\beta$-glycerophosphate ${ }^{21}$ diluted in distilled water were added into each well. Then, media was refreshed every two or three days, and at each refreshing $2 \mathrm{ml}$ of induction media plus $1 \%$ of ascorbic acid ${ }^{22}$ diluted in PBS at $5 \mathrm{mg} / \mathrm{ml}$ and $1 \%$ of $500 \mathrm{mM}$ $\beta$-glycerophosphate were added. After 18 culture days, wells were washed once with PBS and fixed with $4 \%$ paraformaldehyde diluted in distilled water during 20 minutes at room temperature; next, paraformaldehyde was removed, wells were washed once with deionized water and the staining was performed with $2 \%$ Alizarin Red diluted in deionized water $(\mathrm{pH}$ 4.1 ) in 2 wells and Von Kossa solution in one well, the last staining was performed according the protocol from Bonewald et al (2003). Dye solutions were removed after their activation times

\footnotetext{
NF800 Swing-out, Nüve, Turkey; ${ }^{8}$ T6146, Sigma-Aldrich, USA; ${ }^{9}$ D59417C, Sigma-Aldrich, USA; ${ }^{10}$ D5648, Sigma-Aldrich, USA; ${ }^{11}$ 16000044, Gibco, USA; ${ }^{12}$ P3032, Sigma-Aldrich, USA; ${ }^{13}$ G1397, Sigma-Aldrich, USA; ${ }^{14}$ A9528, Sigma-Aldrich, USA; ${ }^{15}$ 12561056, Gibco, USA; ${ }^{16}$ 12664025, Gibco, USA; ${ }^{17}$ 59202C, Sigma-Aldrich, USA; ${ }^{18}$ M7145, Sigma-Aldrich, USA; ${ }^{19}$ 11966025, Gibco, USA; ${ }^{20}$ D8893, Sigma-Aldrich, USA; ${ }^{21}$ G9891, Sigma-Aldrich, USA; ${ }^{22}$ A4544, Sigma-Aldrich, USA.
} 
(5 minutes for Alizarin Red and 20 minutes under UV radiation for Von Kossa) by successive washes with deionized water and, after drying at room temperature, plates were observed under inverted light microscopy.

For adipogenic culture, primary cells were incubated in 6-well plates on the same way as described above for osteogenic differentiation; however, induction media here was composed of 44\% DMEM Advanced ${ }^{\circledR}$, 44\% DMEM glucose-free, 5\% Qualified Fetal Bovine Serum ${ }^{\circledR}, 7 \%$ antibiotic/antimycotic solution and, for each $100 \mathrm{ml}$ of this mix, it was added $50 \mu \mathrm{l}$ of $33 \mu \mathrm{M}$ bio$\operatorname{tin}^{23}(16.3 \mathrm{mg}$ of biotin diluted in $1 \mathrm{ml}$ of distilled water and slow addition of $1 \mathrm{ml}$ of $\mathrm{NaOH}$ ), $100 \mu \mathrm{l}$ of $1 \mu \mathrm{M}$ dexamethasone, $10 \mu \mathrm{l}$ of $100 \mathrm{nM}$ bovine insulin ${ }^{24}(2.87 \mathrm{mg}$ of insulin diluted in $0.5 \mathrm{ml}$ of distilled water with slow addition of $0.5 \mathrm{ml}$ of HCL), $1.7 \mu \mathrm{l}$ of $17 \mu \mathrm{M}$ pantothenic acid $\mathrm{acid}^{25}$ diluted in distilled water, $100 \mu \mathrm{l}$ of $0.2 \mathrm{mM}$ isobutyl-methylxanthine ${ }^{26}$ diluted in dimethyl sulfoxide and $10 \mu \mathrm{l}$ of $5 \mu \mathrm{M}$ rosiglitazone ${ }^{27}$ diluted in dimethyl sulfoxide. After 18 culture days, with media changed every two or three days, cells undergoing adipogenic differentiation were washed with PBS and fixed in paraformaldehyde for one hour at room temperature. Then, paraformaldehyde was removed and wells were washed once with deionized water. Next, a 2\% Oil Red 0 solution in isopropyl alcohol was prepared as stock solution, and the work solution was prepared diluting $24 \mathrm{ml}$ of this stock in $16 \mathrm{ml}$ of distilled water. For staining, the monolayer was covered with work solution and left for 10 minutes before being removed by successive washings with deionized water and observed by inverted light microscope.

For chondrogenic culture, $5 \times 10^{5}$ cells at third passage were centrifuged in $15 \mathrm{ml}$ conical bottom tubes; supernatants were discarded, and, with the cells still in pellet, $0.5 \mathrm{ml}$ of chondrogenic media was added. The chondrogenic induction media was composed of $45 \%$ Advanced $^{\circledR}$ DMEM, 45\% DMEM glucose-free, 10\% antibiotic/antimycotic solution and $250 \mu$ l of TGF- $\beta$ working solution per $5 \mathrm{ml}$ of medium. To prepare a stock solution, $5 \mathrm{~g}$ of TGF- $\beta^{28}$ were diluted in $100 \mu \mathrm{L}$ of citric acid solution $10 \mathrm{mM}$ (pH 3.0). Then, $5 \mu$ l of the TGF- $\beta$ stock solution was diluted in $1250 \mathrm{ml}$ of PBS containing $2 \mathrm{mg} / \mathrm{ml}$ of bovine serum albumin ${ }^{29}$. Pellets were maintained in incubator for 21 days with media refreshing every two or three days. After that, pellets were fixed with paraformaldehyde for 20 minutes, washed 3 times with PBS and immersed in $1 \%$ Alcian Blue dye solution diluted in a 3\% acetic acid solution ( $\mathrm{pH}$ 2.5). After 20 minutes, the dye solution was removed and pellets were successively washed with PBS and stored in PBS until be embedded by paraffin for histological processing and observation by light microscopy.

\section{RESULTS AND DISCUSSION Isolation and culture of BMMCs}

None of the five rabbits showed pain, lameness, infection at the puncture site nor appetite reduction. Both femoral and humerus puncture allowed BMMCs harvesting in enough amount of cells to provide their expansion in vitro. However, humeral puncture occurred more easily and it allowed marrow aspiration in a larger volume $(6 \mathrm{ml}$ on average) than femoral puncture ( $4 \mathrm{ml}$ on average). The average of aspirated marrow in both limbs was greater than the $2 \mathrm{ml}$ quoted by Planka et al. (2008) for aspiration of iliac crest and it was also greater than the $3 \mathrm{ml}$ cited by Eurides et al.

\footnotetext{
${ }^{23}$ B4639, Sigma-Aldrich, USA; ${ }^{24}$ I5500, Sigma-Aldrich, USA; ${ }^{25}$ P2250, Sigma-Aldrich, USA; ${ }^{26}$ I5879, Sigma-Aldrich, USA; ${ }^{27}$ R2408, Sigma-Aldrich, USA; ${ }^{28}$ PHG9204, Gibco, USA; ${ }^{29}$ A4503, Sigma-Aldrich, USA.
}

(2010) and Kim et al. (2012) in humerus aspiration, all in rabbits. According to Pittenger et al. (1999), undifferentiated mesenchymal cells are present in a small percentage of bone marrow $(0.001-0.01 \%$ of the total mononuclear population) and, thus, collecting greater bone marrow volume could increase the probability of a successful mesenchymal stromal cells isolation and expansion. Although it was possible to observe presence of fat and clots in the marrow aspirated, even with heparin addition, the methods here proposed can be considered effective, once those substances were properly removed bycell-strainer filtering, providing an ideal liquid solution for plating on the culture dishes.

Primary manual counting showed the average of $4.7 \times 10^{6}$ mononuclear cells per ml of aspirated bone marrow, which is higher than the average of $3.4 \times 10^{6}$ reported by Im et al. (2001), close to the average of $5 \times 10^{6}$ reported by Yanai et al. (2005) and below the average of $20 \times 10^{6}$ cells $/ \mathrm{ml}$ reported by Planka et al. (2008), all references of cells isolated from rabbits' bone marrow. These differences between numbers of isolated mononuclear cells may be related to the protocol used for cell harvesting and also to the variation that can occur naturally between individuals of same species and under same conditions (Eurides et al. 2010). According Yew et al. (2012), age is another factor that might influence in the number of cells isolated, once evidences have documented that human mesenchymal stromal cells decrease in accordance to ageing, both in number and in efficiency.

As there was large amount of red blood cells in the filtrate, it was not possible to visualize the adherent mononuclear cells during the early cultivation due to red cells superposition. However, after the first media refreshing, the amount of red cells in suspension was reduced and it was possible to observe presence of fibroblastoide-shaped cells attached on culture flask surface, albeit at a low density. As media refreshing was being done, preceded by washing with PBS, attached cells and their confluence were clearly identified.

\section{BMMCs' proliferation}

DMEM-P was the first media choice for rabbits' BMMCs harvesting when this study was carried out; comparing the cell growing to results obtained by other researchers using a similar media, it was observed that these cells were presenting a delay to reach confluence and there was also a lower amount of viable cells when passages were done than those values referred by other researches. Based on these initial results, it was decided to perform a cell proliferation test for DMEM-P, which confirmed a low BMMCs proliferation rate in this media. Figure 2A shows BMMCs reaching their maximum average of proliferation on the fourth culture day with a total of $12 \times 10^{4}$ cells; after five culture days, this average decreased extensively, and on the sixth day the count revealed a value lower than that number of cells initially seeded in each well to start the test, suggesting that this media was probably not the best one for BMMCs isolation and expansion.

In this context, the formulations of DMEM'S and $\alpha$-MEM media were tested for BMMCs proliferation. Even before 
doing this test it was observed that BMMCs reached their confluence in T75 flasks to do the first passage earlier when cultured in DMEM'S (approximately after 15 culture days) than in $\alpha$-MEM media (approx. after 21 culture days). Then, proliferation assay confirmed this tendency of the cells growing faster in DMEM'S than in $\alpha$-MEM media. Until the fifth day, proliferation curves indicated that cells proliferated with similar number of cells in both media, however, from the sixth day onwards, cells cultured in DMEM'S maintained their proliferation at a rate 20 to $40 \%$ higher than those grown in $\alpha$-MEM (Fig.2B). It can also be observed that the peak of BMMCs proliferation in $\alpha$-MEM occurred on the fifth culture day, with a significant reduction of $50 \%$ in the number of viable cells on the sixth day. Whilst for those cells cultured in DMEM'S it was noted two peaks, one after seven and another after ten culture days, and both of them were higher than those values corresponding to $\alpha$-MEM segment.

Comparing the data in Table 1 and proliferation curves obtained with DMEM-P, DMEM'S, $\alpha$-MEM media (Fig.2), it can be observed that the utilization of a more elaborated media (DMEM'S), associating L-glutamine and nonessential amino acids to a mix of specific media and BFS of superior quality, increased cell proliferation. However, it is suggested that this increase can be also related to glucose level variation between culture media, once even with L-glutamine, nonessential amino acids, and qualified BFS supplementation, there was still a significant difference between

A

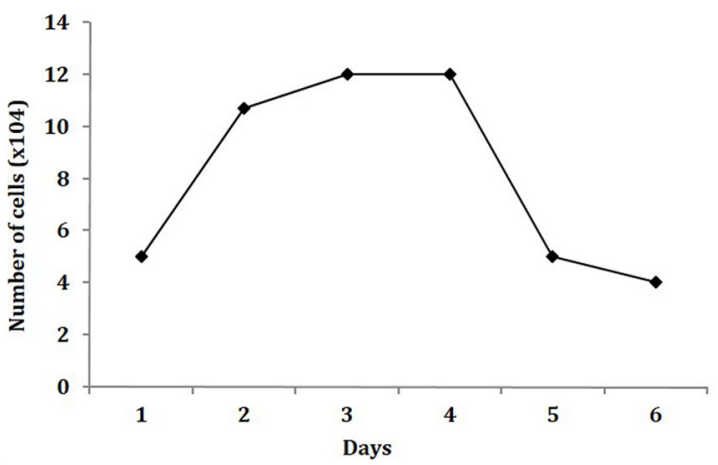

B

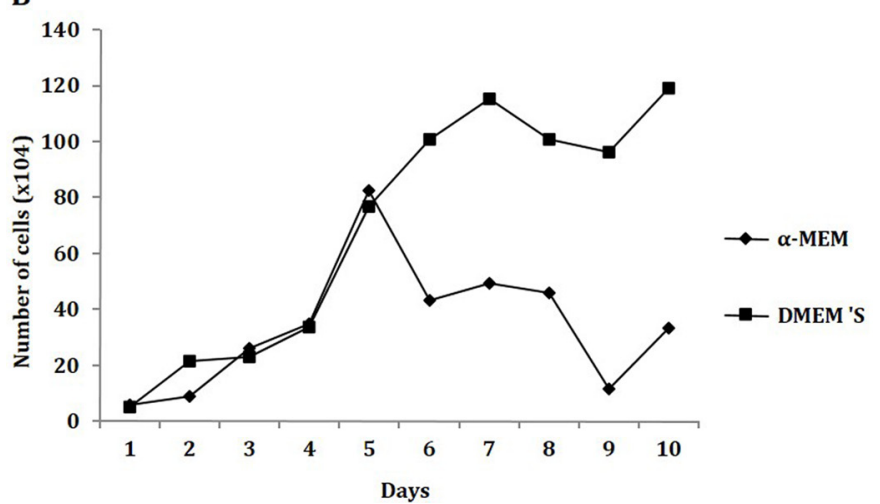

Fig.2. (A) Proliferation curves (averages) of BMMCs from rabbits at fourth passage cultured in DMEM-P, DMEM'S (B) and $\alpha$-MEM media, indicating that the cells have adapted and proliferated better when cultured in DMEM'S media.
Table 1. Number of BMMCs from rabbits' bone marrow at third passage (means) cultured between 1 and 10 days in DMEM-P, $\alpha$-MEM and DMEM'S media, $n=3 /$ day/media

\begin{tabular}{cccc}
\hline Culture days & DMEM-P & $\alpha$-MEM & DMEM'S \\
\hline 1 & 500000.0 & 56666.7 & 50000.0 \\
2 & 106666.7 & 90000.0 & 213333.0 \\
3 & 120000.0 & 260000.0 & 230000.0 \\
4 & 120000.0 & 346666.7 & 336666.7 \\
5 & 50000.0 & 823333.3 & 766669.7 \\
6 & 40000.0 & 433333.3 & 1006667.0 \\
7 & - & 493333.3 & 1153333.0 \\
8 & - & 460000.0 & 1006667.0 \\
9 & - & 113333.3 & 960000.0 \\
10 & - & 333333.3 & 1190000.0 \\
Standard deviation & 34889.6 & 219287.0 & 41439.7
\end{tabular}

proliferation curves provided by DMEM'S and $\alpha$-MEM; analyzing each media formulation proposed here, it was noticed a difference between glucose levels.

The benefits due to glucose increment in media for mesenchymal stromal cells culture is a subject that have been treated with caution in the field of cell therapy. As it is well known, glucose is an essential source of cellular energy and it acts as an important substrate for protein and lipid synthesis (Scheepers et al. 2004). Thus, cell proliferation and metabolism are also modulated by glucose, both in physiological and in pathological conditions ( $\mathrm{Li}$ et al. 2007). However, studies have shown that high glucose concentrations can impair original cellular functions such as apoptosis, viability and proliferation; besides, it can change the ability of primary cells in forming colonies in vitro and in vivo, regardless of their origin tissue (Li et al. 2007). High glucose concentrations may also modify the gene expression and direct the differentiation of stem cells to the adipogenic over the chondrogenic and osteogenic lineages (Kearts \& Khan 2012). On the other hand, glucose depletion improves these properties due to the overall beneficial effects already described of caloric restriction for stem cells, such as delay of cell death, senescence and ageing (Choudhery et al. 2012). These reports suggest that the damage caused by glucose level deregulation may affect some properties of undifferentiated cells in a long-term and on irreversible way (Bastianelli et al. 2014).

Therefore, the proliferation assay results of this study have corroborated the reports above discussed regarding to glucose interference in primary mononuclear cells cultivation. For DMEM-P media production, it was used only a low glucose media $(1000 \mathrm{mg} / \mathrm{L})$ which might have not provided all the nutrients necessary for obtaining a good cell proliferation rate. For DMEM'S, besides supplementation with L-glutamine and non-essential amino acids, an equivalent mix of a high glucose media $(4500 \mathrm{mg} / \mathrm{L})$ and a no glucose media were used, resulting in a final intermediary glucose level of $2250 \mathrm{mg} / \mathrm{L}$, which provided the best results in this assay. In turn, the $\alpha$-MEM media combined the same supplementation with L-glutamine and non-essential amino acids in a low glucose media, also resulting in the final glucose concentration of $1000 \mathrm{mg} / \mathrm{L}$ and giving a better proliferation curve than DMEM-P, but lower than that provided by DMEM'S media. 


\section{BMMCs' differentiation}

The protocol for mesenchymal stem cells differentiation proposed by Sarugaser et al. (2009) allowed rabbits' BMMCs to differentiate into osteogenic, adipogenic and chondrogenic lineages, as suggested by ISCT to assess stem cells multipotenciality. Under inverted light microscopy, nodules suggesting bone formation and a positive staining for mineral deposits were identified in the osteogenic culture (Fig.3A), which was visible macro and microscopically, both by the red color arising from Alizarin Red dye (Fig.3B and 3C) and by the black deposits by Von Kossa staining (Fig.3D and 3E). In the adipogenic differentiation plates, cells filled with a greasy content were identified by inverted light microscopy (Fig.4A), which was already macroscopically visible due to presence of oily content spread on culture dishes (Fig.4B); adipogenic differentiation was microscopically confirmed with positive staining of intracellular fat content by Oil Red 0 dye solution (Fig.4C). Histological processing of pellets derived from chon-

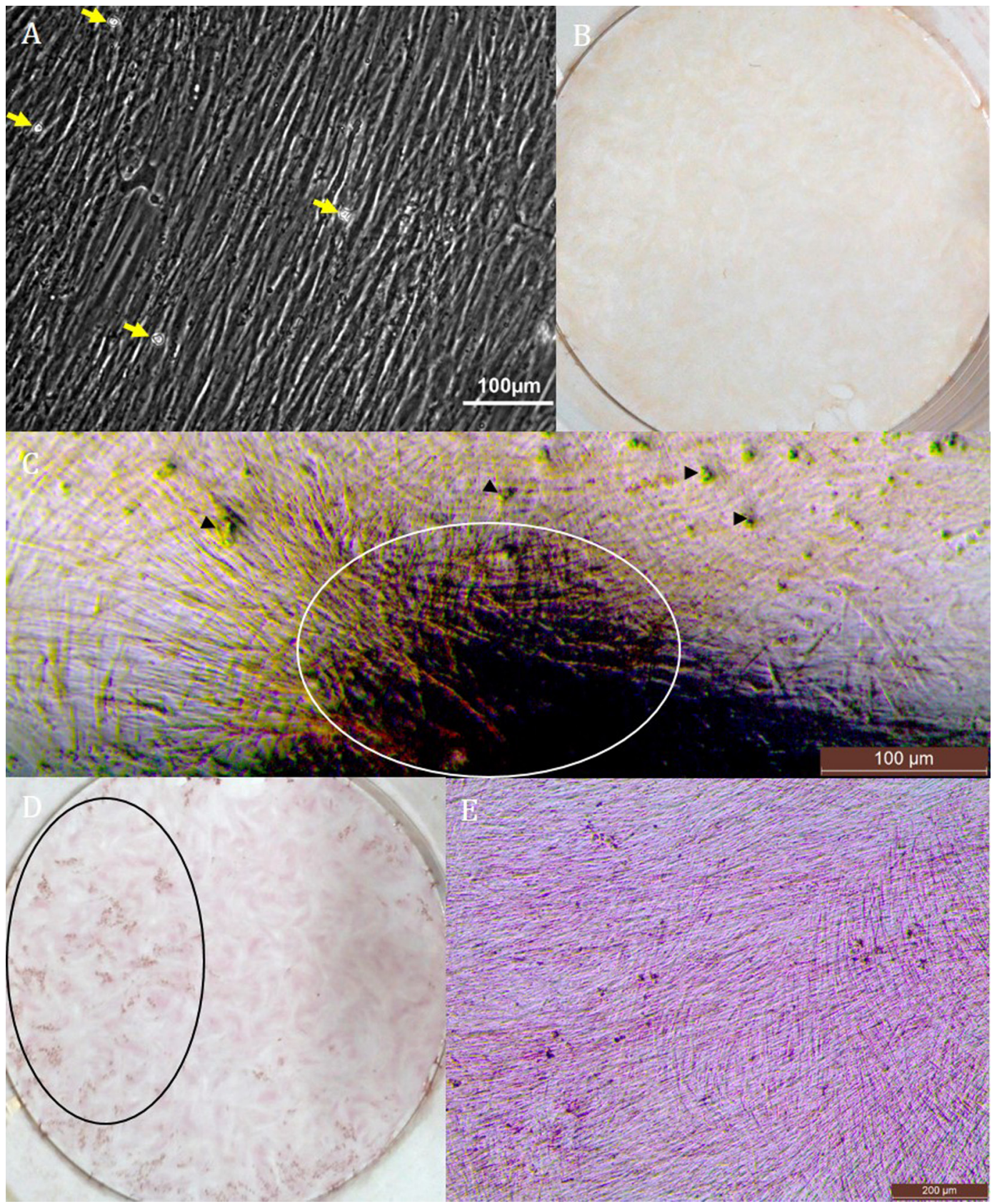

Fig.3. Images of the BMMCs culture after 18 days under osteogenic differentiation induction. (A) Direct observation of the culture plate by inverted light microscope without staining. Note the presence of nodule formation (yellow arrows) on the cell monolayer surface suggesting bone formation. (B) Macroscopic view after staining with Alizarin Red. (C) Image by inverted light microscopy showing presence of bone nodules formation (arrowheads) with Alizarin Red impregnation at the edges of culture dish (circled area). (D) Macroscopic view of culture stained with Von Kossa, demonstrating the presence of mineral deposits stained in black distributed around the plate (circle). (E) Image by inverted light microscopy confirming the presence of dots stained in black by Von Kossa distributed around the plate suggesting the presence of mineral content. 
drogenic differentiation to analyze by light microscopy was hampered due to their small dimensions (Fig.4D), especially at the step of embedding in paraffin; however, the procedure enabled to identify presence of cartilage matrix typically stained in blue by Alcian blue staining (Fig.4E).
Therefore, as tri-lineage differentiation was not hampered in presence of L-glutamine and nonessential amino acids, this study shows that the supplementation and glucose level of DMEM'S media favored MSCs proliferation maintaining their multipotentiality

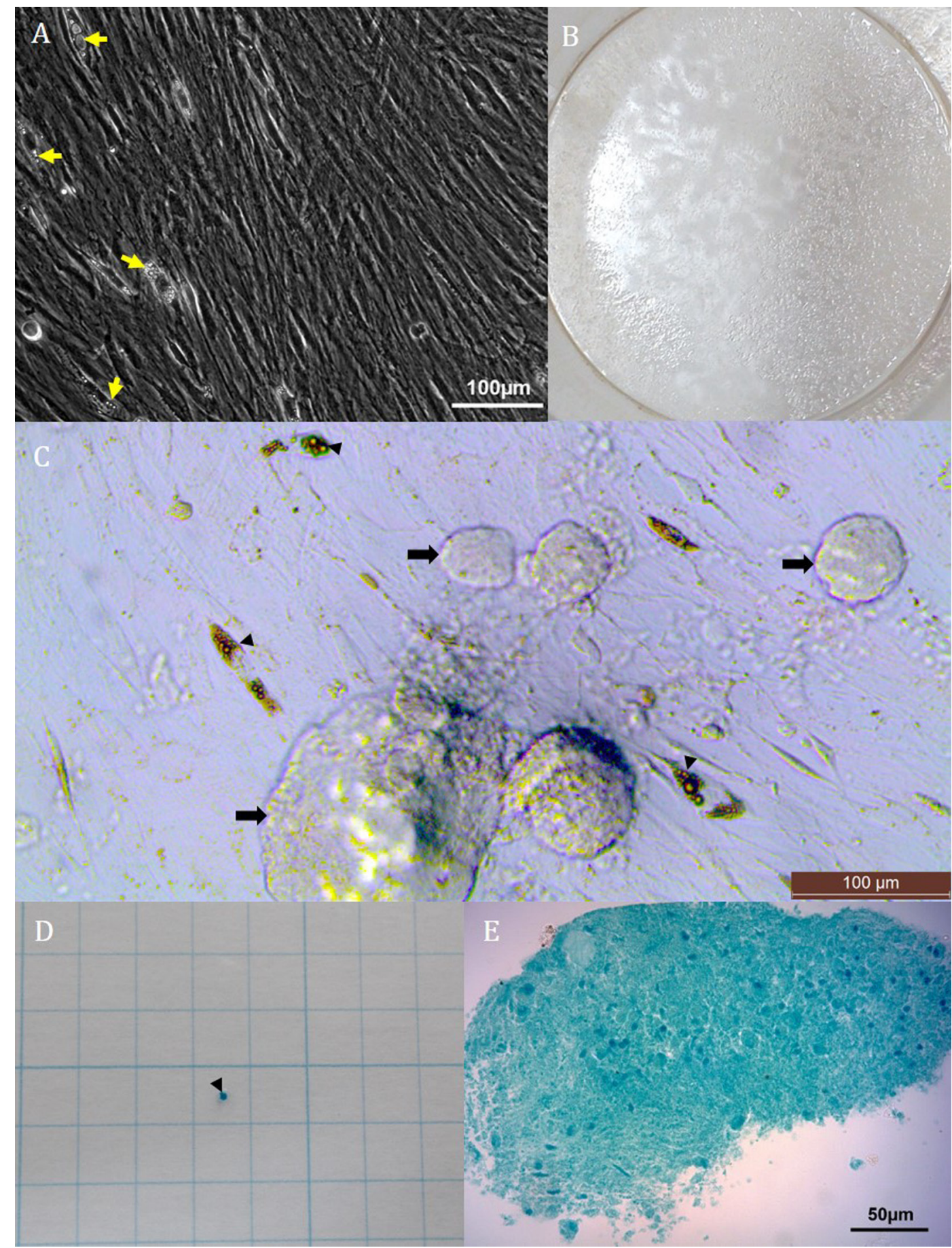

Fig.4. Images of the BMMCs culture after 18 days under adipogenic differentiation and 21 days under chondrogenic differentiation. (A) Direct observation of adipogenic culture by inverted light microscope without staining. Note the presence of intracellular vesicles filled with greasy content (yellow arrows). (B) Macroscopic view of the adipogenic culture after staining with Oil Red 0, indicating the presence of oily content distributed throughout the dish. (C) Image by inverted light microscopy confirming the presence of fat content stained by Oil Red 0, which was visible within intracellular vesicles (arrowheads) and in the extracellular environment (arrows). (D) Small pellet formed after 21 days of chondrogenic culture stained with Alcian Blue (arrowhead) on graph paper. (E) Histological section of the pellet observed by light microscopy, showing matrix with cartilaginous aspect, typically stained by Alcian Blue. 


\section{CONCLUSION}

It was concluded that both humerus and femur can be considered effective for MSCs harvesting and expansion from rabbits' bone marrow and that, among the media tested, DMEM'S matched better the nutrients to optimize the cell proliferation with multipotentiality preservation. Thus, researchers who usually work with a rabbit model for experiments using rabbits' mesenchymal stromal cells may be able to reproduce the techniques presented here to harvest and characterize them properly.

Acknowledgments.- Founding from CAPES, FAPEMIG, CNPq and JHS Biomateriais is gratefully acknowledged.

Conflict of interest statement.- The authors have no competing interests.

\section{REFERENCES}

Bastianelli D., Siciliano C., Rosa P., Coccia A., Murdoch C., Bordin A., Mangino G., Pompilio G., Calogero A. \& De-Falco E. 2014. Influence of egr-1 in cardiac tissue-derived mesenchymal stem cells in response to glucose variations. BioMed Res. Int. Available on <http://www.ncbi.nlm.nih. gov/pmc/articles/PMC4054710/pdf/BMRI2014-254793.pdf> Access on 03 Oct. 2014.

Bonewald L.F., Harris S.E. \& Rosser J. 2003. Von Kossa staining alone is not sufficient to confirm that mineralization in vitro represents bone formation. Calcif. Tissue Int. 72:537-574.

Castañeda S., Largo R., Calvo E., Rodríguez-Salvanés F., Marcos M.E., DíazCuriel M. \& Herrero-Beaumont G. 2006. Bone mineral measurements of subchondral and trabecular bone in healthy and osteoporotic rabbits. Skeletal Radiol. 35:34-41.

Choudhery M.S., Khan M., Mahmood R., Mohsin S., Akhtar S., Ali F., Khan S.N. \& Riazuddin S. 2012. Mesenchymal stem cells conditioned with glucose depletion augments their ability to repair-infarcted myocardium. J. Cel. Med. 16:2518-2529.

Dawson E., Mapili G., Erickson K., Taqvi S. \& Roy K. 2008. Biomaterials for stem cell differentiation. Adv. Drug Deliv. Rev. 60:215-228.

Dominici M., Le Blanc K., Mueller I., Slaper-Cortenbach I., Marini F., Krause D., Deans R., Keating A., Prockop Dj. \& Horwitz E. 2006. Minimal criteria for defining multipotent mesenchymal stromal cells: the International Society for Cellular Therapy position statement. Cytotherapy 8:315-317.

Eurides D., Oliveira B.J.N.A., Souza L.A., Silva L.A.F., Daleck C.R. \& Freitas P.M.C. 2010. Acquirement of bone marrow mononuclear cells by puncture of the humerus tubercle of rabbits. Ars Vet. 2:71-76.

Griffith L.G. \& Naughton G. 2002. Tissue engineering - current challenges and expanding opportunities. Science 295:1009-1014.

Im G.I., Kim D.Y., Shin J.H., Hyun C.W. \& Cho W.H. 2001. Repair of cartilage defect in the rabbit with cultured mesenchymal stem cells from bone marrow. J. Bone Joint Surg. Br. 83:289-294.

Kearts E. \& Khan Z.A. 2012. Unique responses of stem cell-derived vascular endothelial and mesenchymal cells to high levels of glucose. PLoS One. 7. Available on <http://www.ncbi.nlm.nih.gov/pmc/articles/ PMC3368917/pdf/pone.0038752.pdf> Access on Oct. 3, 2014.

Kim S.S., Kang M.N., Lee K.Y., Lee M.J., Wang L. \& Kim H.J. 2012. Therapeutic effects of mesenchymal stem cells and hyaluronic acid injection on osteochondral defects in rabbits' knees. Knee Surg. Relat. Res. 24:164-172.

Kotobuki N., Ioku K., Kawagoe D., Fujimori H., Goto S. \& Ohgushi H. 2005. Observation of osteogenic differentiation cascade of living mesenchymal stem cells on transparent hydroxyapatite ceramics. Biomaterials 26:779-785.
Lee T.-C., Lee T.-H., Huang Y.-H., Chang N.-K., Lin Y.J., Chien P-W.C., Yang W.H. \& Lin M.H.-C. 2014. Comparison of surface markers between human and rabbit mesenchymal stem cells. PlosOne 9:e11390. Available on <http://www.ncbi.nlm.nih.gov/pmc/articles/PMC4224397/pdf/pone. 0111390.pdf> Access on Dec. 3, 2015.

Li Y., Chen S.-K., Li L., Ling Q., Wang X.-L. \& Lai Y.-X. 2015. Bone defect animal models for testing efficacy of bone substitute biomaterials. J. Othop. Trans. 3:95-104.

Li Y-M., Schilling T., Benisch P., Zeck S., Meissner-Weigl J., Schneider D., Limbert C., Seufert J., Kassem M., Schütze N., Jakob F. \& Ebert R. 2007. Effects of high glucose on mesenchymal stem cell proliferation and differentiation. Biochem. Biophys. Res. Commun. 363:209-215.

Ma X., Sun Y., Cheng X., Gao Y., Hu B., Wen G., Qian Y., Gu W., Mao Y. \& Liu W. 2015. Repair of osteochondral defects by mosaicplasty and allogeneic BMSCs transplantation. Int. J. Clin. Exp. Med. 8:6053-6059.

Mehrabani D., Babazadeh M., Tanideh N., Zare S., Hoseinzadeh S., Torabinejad S. \& Koohi-Hosseinabadi O. 2015. The healing effect of adipose-derived mesenchymal stem cells in full-thickness femoral articular cartilage defects of rabbit. Int. J. Organ Transplant. Med. 6:165-175.

Pelizzo G., Avanzini M.A., Cornaglia A.I., Osti M., Romano P., Avolio L., Maccario R., Dominici M., De Silvestri A., Andreatta E., Costanzo F., Mantelli M., Ingo D., Piccinno S. \& Calcaterra V. 2015. Mesenchymal stromal cells for cutaneous wound healing in a rabbit model: pre-clinical study applicable in the pediatric surgical setting. J. Trans. Med. 13. Available on <http://www.ncbi.nlm.nih.gov/pmc/articles/PMC4495634/> Access on Dec. 3, 2015.

Pittenger M.F., Mackay A.M., Beck S.C., Jaiswal R.K., Douglas R., Mosca J.D., Moorman M.A., Simonetti D.W., Craig S. \& Marshak D.R. 1999. Multilineage potential of adult human mesenchymal stem cells. Science 284:143-147.

Planka L., Gal P., Kecova H., Klima J., Hlucilova J., Filova E., Amler E., Krupa P., Kren L., Snerc R., Urbanova L., Lorenzova J. \& Necas A. 2008. Allogeneic and autogenous transplantations of MSCs in treatment of the physeal bone bridge in rabbits. BioMed Central Biotechnol. 8. Available on $<\mathrm{http}: / /$ www.biomedcentral.com/1472-6750/8/70> Access on Sept. 16, 2014.

Sarugaser R., Ennis J., Stanford W.L. \& Davies J.E. 2009. Isolation, propagation, and characterization of human umbilical cord perivascular cells (HUCPVCs). Methods Mol. Biol. 482:269-279.

Scheepers A., Joost H.G. \& Schürmann A. 2004. The glucose transporter families SGLT and GLUT: molecular basis of normal and aberrant function. PEN J. Parenter. Enteral Nutr. 28:364-37.

Semyari H., Rajipour M., Sabetkish S., Sabetkish N., Abbas F.M. \& Kajbafzadeh A. 2015. Evaluating the bone regeneration in calvarial defect using osteoblasts differentiated from adipose-derived mesenchymal stem cells on three different scaffolds: an animal study. Cell Tissue Bank. Available on <http://link.springer.com/article/10.1007\%2 Fs10561-015-9518-5> Access on Dec. 3, 2015.

Tognoli G.K., Olsson D.C., Martins D.B., Santos Júnior E.B., Salbego F.Z., Oliveira G.K., Braga F.V.A., Raiser A.G., Dexengrini R., Cruz F.S.F., Castro M.B., Rosa M.C., Carregaro A.B. \& Pipi N.L. 2009. Bone marrow mononuclear cells autotransplant in experimental corneal ulcer in dogs. Ciência Rural 39:148-155.

Yanai T., Ishii T., Chang F. \& Ochiai N. 2005. Repair of large full-thickness articular cartilage defects in the rabbit: the effects of joint distraction and autologous bone marrow-derived mesenchymal cell transplantation. J. Bone Joint Surg. (Bras.) 87:721-729.

Yew T.L., Huang T.F., Ma H.L., Hsu Y.T., Tsai C.C., Chiang C.C., Chen W.M. \& Hung S.C. 2012. Scale-up of MSC under hypoxic conditions for allogeneic transplantation and enhancing bony regeneration in a rabbit calvarial defect model. J. Orthop. Res. 30:1213-1220. 